\title{
CHEMICAL AND BIOLOGICAL PROPERTIES OF A PURIFIED LYMPHORETICULAR-STIMULATING FRACTION OF CORYNEBACTERIUM PARVUM (PROPIONIBACTERIUM ACNES TYPE I)
}

\author{
C. Adlam, D. E. Reid, A. J. Marshall* and P. Torkington $\dagger$ \\ Departments of Bacteriology, ${ }^{*}$ Protein Chemistry, and $\dagger$ Physical Chemistry, Wellcome Research \\ Laboratories, Langley Court, Beckenham, Kent, BR3 $3 B S$
}

\section{Plate XXXV}

THE chemical basis for the lymphoreticular-stimulating properties of Corynebacterium parvum and related organisms has been the subject of study for several years. Prévot and co-workers showed that activity, as measured by enhancement of carbon clearance, appeared to reside in the cell wall and was resistant to heat and formalin treatment. Lysis of the organisms, either mechanically or by phage, reduced or destroyed activity (Prévot and Thouvenot, 1964; Prévot, Nguyen-Dang and Thouvenot, 1968).

In more recent studies, several groups of workers have purified extracts from C.parvum cells or culture filtrates and tested them in a variety of biological-assay systems. Migliore-Samour $e t$ al. (1974), using a water extract of delipidated organisms which they considered to be peptidoglycan, showed adjuvant and antiviral effects. Lallouette et al. (1977) described a large-molecularweight anti-tumour fraction consisting of protein and carbohydrate. Dawes, Tuach and McBride (1974) and McBride, Dawes and Tuach (1976) examined the properties of antigens released from $C$. parvum cells during growth or by mild hydrolysis. Two antigens were obtained; one, predominantly carbohydrate, was shown to have cell-binding properties and the other, mainly lipid, had anti-tumour activity. Fauve (1975) and Russell et al. (1976) described $C$. parvum-derived lipids that had stimulatory and chemotactic properties. Finally, Millman, Scott and Halbherr (1977) partially purified an RNA-containing fraction from the cytoplasm of $C$. parvum that had anti-tumour properties.

It is generally accepted that isolated cell walls or cell-wall fractions resulting from mechanical disintegration, phage-treatment or autolysis of $C$. parvum cells at best retain only part of the stimulatory activity of the whole cells and, at worst, may be totally inactive (Prévot $e$ t al., 1968; Adlam, Reid and Torkington, 1975; Azuma et al. 1975; Millman et al., 1977).

In a more recent study, Riveros-Moreno. Bomford and Scott (1978) found that the residual anti-tumour activity of cell walls derived from disrupted $C$. parvum cells was due to "non specific" macrophage-activation effects; attempts to restore full stimulatory activity to the cell-wall preparations by emulsifying them in oil or attaching them to oil droplets were unsuccessful.

In the present study, rather than use mechanically disintegrated cells, we have treated whole organisms chemically and with enzymes to try to remove components unnecessary for stimulation and to leave behind materials that retain the immuno-stimulatory properties of the whole organisms. In our

Received 16 Feb. 1978; revised version accepted 25 Oct. 1978. 
earlier work (Adlam et al., 1975) we showed that hot phenol-water extraction of whole cells, followed by treatment with lipid solvent and enzyme digestion, produced an active but impure product as judged by electron microscopy. Our original method has now been improved to yield a cleaner final product with immuno-stimulatory properties.

\section{MATERIALS AND METHODS}

Strain of C. parvum. Cummins and Johnson (1974) showed that organisms known as C. parvum should be reclassified as Propionibacterium acnes, $P$. granulosum or $P$. avidum. In the present study the strain used (Wellcome no. CN6134) was a typical $P$. acnes type I by all the biochemical and serological tests that were used.

Extraction method. Freeze-dried organisms $50 \mathrm{~g}$, grown and harvested as previously described but without formalin inactivation (Adlam and Scott, 1973), were subjected to four phenol-water extractions in a volume of 2 litres at $65^{\circ} \mathrm{C}$ (Westphal and Jann, 1965). Aqueous and phenolic phases were discarded and the resultant insoluble residue and interface material were retained, washed, dialysed and freeze dried. This residue will be referred to as PWIR (phenolwater-insoluble residue). Extraction of PWIR ( $2.5 \mathrm{~g})$ with $200-\mathrm{ml}$ volumes of $0.1 \mathrm{~N}$ sodium hydroxide at $37^{\circ} \mathrm{C}$ was repeated until release of free amino groups, as detected by 2.4 dinitrofluoro benzene (Ghuysen, Tipper and Strominger, 1966), had ceased. After dialysis, the residue was extracted three times for $15 \mathrm{~min}$. with $200-\mathrm{ml}$ volumes of $10 \%$ trichloracetic acid at $37^{\circ} \mathrm{C}$. The acid was removed by dialysis and the residue resuspended at $10 \%$ in $0.05 \mathrm{M}$ phosphate buffer, pH 7.4, containing $0.22 \mu \mathrm{m}$-filtered pronase (Sigma) $1 \mathrm{mg} / \mathrm{ml}$ and sodium azide $0.02 \%(\mathrm{w} / \mathrm{v}$ ) as preservative. Digestion was carried out with agitation at $37^{\circ} \mathrm{C}$ until no further release of free amino groups was detected. The resultant material was washed and resuspended as a $10 \%$ suspension in $0.05 \mathrm{M}$ phosphate buffer at $p \mathrm{H} 7.2$ containing $1 \mathrm{mg} / \mathrm{ml}$ of $0.22 \mu \mathrm{m}$-filtered ribonuclease (Sigma, type IIIB) and azide and digested at $37^{\circ} \mathrm{C}$ until release of 260 -nm-absorbing nucleotides was complete. The material was then similarly extracted with $0 \cdot 22-\mu \mathrm{m}$-filtered DNAase(Sigma, $0.25 \mathrm{mg} / \mathrm{ml}$ ). After washing, the residue was six times extracted with mixing for $15 \mathrm{~min}$. at room temperature in chloroform, methanol and $1 \mathrm{~N}$ hydrochloric acid $(66: 33: 1, \mathrm{v} / \mathrm{v})$. Extraction was carried out on a $10 \%$ suspension of material in solvent. Finally the material was extracted in a Soxhlet apparatus sequentially with redistilled ethanol, redistilled chloroform and redistilled ether at the boiling point of each solvent for $4 \mathrm{~h}$. The resulting residue, referred to as final product, was dried under a stream of warm nitrogen before being subjected to biological and chemical assay.

Preparation of cell walls. Washed organisms were mechanically ruptured with glass ballotini no. 14 in a rotary disintegrator (Novotny, 1964). After removal of the ballotini by filtration through a sintered-glass funnel, the suspension was subjected to low-speed centrifugation $(300 \mathrm{~g}$ for $5 \mathrm{~min}$.) to remove intact cells. The supernate, containing broken organisms, was centrifuged at $12000 \mathrm{~g}$ for $20 \mathrm{~min}$., washed three times in distilled water and digested with pronase. After further washing, the cell walls were freeze dried.

Neutral-sugar chromatography. Samples were hydrolysed in sealed ampoules with $2 \mathrm{~N} \mathrm{HCl}$ for $4 \mathrm{~h}$ at $100^{\circ} \mathrm{C}$. The filtered hydrolysate was evaporated to dryness several times, water being added between the evaporations. The final residue was suspended in pyridine, centrifuged and the supernate used for thin-layer chromatography on silica-gel plates (Schleicher and Schull, Dassel, West Germany) by the method of Hansen (1975). The solvents used were isopropanol, acetone, $0 \cdot 1 \mathrm{M}$ lactic acid $(4: 4: 2, \mathrm{v} / \mathrm{v})$. Spots were visualised with the aniline, diphenylamine, acetone, phosphoric acid reagent of Hansen (1975).

Amino-acid chromatography. Samples were hydrolysed in sealed ampoules with $6 \mathrm{~N} \mathrm{HCl}$ for $18 \mathrm{~h}$ at $100^{\circ} \mathrm{C}$. The filtered hydrolysate was evaporated to dryness several times, water being added between evaporations. The final residue was resuspended in $10 \%$ isopropanol and two-dimensional thin layer chromatography was done on Cellulose F Plates (Merck, Darmstadt, West Germany) by the method of Haworth and Heathcote (1969). Solvents used were 2-propanol, butanone, $1 \mathrm{~N} \mathrm{HCl}(60: 15: 25, \mathrm{v} / \mathrm{v})$ and 2-methyl-propanol, 2-butanone, propanone, 
methanol, water, $0 \cdot 880$ ammonia $(40: 20: 20: 1: 14: 5$, v/v). Spots were visualised with the ninhydrin, collidine, acetic acid reagent of Cowgill and Pardee (1957).

Amino-acid analysis. After the same hydrolysis of samples as for thin-layer chromatography, the final residue was suspended in water and analysed on a Rank Hilger Chromaspek automatic amino-acid analyser.

Infrared analysis. Solid samples were ground between ground-glass plates, then dispersed in standard 16-mm diameter potassium-bromide discs by grinding approximately $1.5 \mathrm{mg}$ with 350 $\mathrm{mg}$ of potassium bromide in a ball mill. Analysis was done in a Perkin Elmer 580 Spectrometer over the range $300-4000 \mathrm{~cm}^{-1}$.

Electron microscopy. Samples were fixed in $0.1 \mathrm{M}$ phosphate buffer at $p \mathrm{H} 7.2$ containing $2 \%$, glutaraldehyde post-fixed in osmium fixative (Palade, 1952) and dehydrated in a graded series of ethanol concentrations with acetone as the final step. After embedding in araldite, 50-nm sections were obtained on an LKB Ultratome III, picked up on 200-mesh grids and double stained with $2 \%$ uranyl acetate and Reynold's lead citrate (Reynolds, 1963). Examination was made in a Philips 300 electron microscope.

Lipid determination. Lipid measurements were obtained indirectly by infrared spectroscopy, as described above, and directly by the weight of solvent-soluble material removed by a modification of the extraction method of Folch, Lees and Sloane-Stanley (1957). The modification consisted of adding $1 \mathrm{~N}$ hydrochloric acid to the chloroform-methanol mixture usually employed so that the final solvent composition was: 66 parts chloroform, 33 parts methanol, 1 part hydrochloric acid.

Carbohydrate determinations. Estimates of "total carbohydrate", excluding the amino sugars which were not detected; were made by the phenol/sulphuric acid and by the anthrone methods (Herbert, Phipps and Strange, 1971). For each sample, six determinations were made by each method.

Antitumour activity. Groups of 10 male CBA mice weighing 16-20 g (Wellcome Breeding Colony) received varying doses of $C$. parvum or fractions intravenously in saline 4 days before intravenous challenge with $10^{5} \mathrm{~T} 3$ fibrosarcoma cells; 14 days later, the animals were killed and their lungs were inflated with Indian ink, dissected out, and stored in fixative before the counting of tumour nodules.

Spleen-and liver-weight. Groups of 10 female random-bred mice weighing $16-20 \mathrm{~g}$ each (Olac, Shaw's Farm, Blackthorne, Bicester, Oxon) received varying doses of C. parvum or fractions intravenously in saline. After 14 days the animals were killed and their spleens and livers were weighed.

Rabbit pyrogenicity. Groups of three New Zealand white rabbits (Ranch Rabbits, Copthorne, Sussex) received intravenous injections, in 0.4-ml volumes, of varying doses of $C$. parvum or fractions in saline. Rectal-temperatures were recorded by thermocouple for $5 \mathrm{~h}$.

Mouse toxicity. Groups of 10 male random-bred mice weighing 14-16 g each (Schofield, Intake Head, Delph, Oldham, Lancs) received varying doses of $C$. parvum or fractions intraperitoneally and were weighed at intervals up to 7 days.

\section{RESULTS}

\section{Extraction of the organisms}

In a typical experiment, phenol-water extraction of the whole organisms removed approximately $50 \%$ of the starting weight into the aqueous and phenolic phases, leaving a white insoluble residue (PWIR). Examination of this material by electron microscopy showed that it was a mixture of organisms that appeared to be intact and organisms that had partially or completely released their cytoplasmic contents (fig. 1). Preliminary experiments showed that whereas PWIR possessed lymphoreticular-stimulating activity, this was destroyed by exhaustive treatment with hot trichloracetic acid (TCA). Three 
15 -min. extractions at $37^{\circ} \mathrm{C}$, however, could be made without destroying activity.

Dilute alkali extraction at $37^{\circ} \mathrm{C}$ was found to reduce activity far less than acid treatment and was successfully used further to remove cytoplasmic components. These were detected by monitoring digest supernates at $260 \mathrm{~nm}$.

Release of free amino groups was monitored during pronase treatment and several changes of enzyme were required before digestion was complete. Similarly it was necessary to make repeated RNAase and DNAase extractions to release all 260-nm-absorbing nucleotides.

The effectiveness of the lipid-solvent extraction procedure on the enzymedigested material was assessed by submitting duplicate $500-\mathrm{mg}$ samples of starting material, PWIR and final product to two lipid extractions with chloroform, methanol, hydrochloric acid. The percentage by weight of lipid removed was calculated by difference and the results obtained were: $0.475 \%$ for the starting material, $0 \cdot 164 \%$ for PWIR and $0 \cdot 104 \%$ for the final product.

The low yield of lipids extracted from the starting material by these solvents prompted an investigation of the quantities of extractable lipid present in other batches of the same organism and in other anaerobic diphtheroid strains. The low results obtained with strain CN6134 were confirmed-values ranged from 0.24 to $0.88 \%$ - but higher values were obtained with other strains, i.e., $4.82 \%$ for $P$. granulosum strain CN6293, $5.34 \%$ for P. lymphophilum strain CN6294 and $2.85 \%$ for $P$. avidum strain CN6967.

Final material examined by electron microscopy appeared as relatively clean but intact bacterial cell walls. No striking surface structures were observed (fig. 2). In a typical experiment $10-15 \%$ by weight of the starting material was recovered as the final product.

\section{Carbohydrate determinations}

Estimates of 'total carbohydrate' content, excluding amino sugars, gave similar results for the starting material, PWIR and final product. Starting material gave a mean percentage carbohydrate value of $10.45 \%$ by anthrone and $14.97 \%$ by phenol/sulphuric acid; PWIR gave $8.70 \%$ by anthrone and $12.98 \%$ by phenol/sulphuric acid. Final product gave $13.77 \%$ by anthrone and $13.97 \%$ by phenol/sulphuric acid.

\section{Infrared analysis}

Infrared analysis of the starting material, PWIR and final product showed that although not indicated by the direct measurements of 'total carbohydrate' described above, considerable carbohydrate enrichment had occurred during the extraction process (fig. 3). This was most easily observed by an increase in the peak height due to $\mathrm{C}-\mathrm{OH}$ absorbance at $1070 \mathrm{~cm}^{-1}$ relative to $\mathrm{C}=\mathrm{O}$ at $1650 \mathrm{~cm}^{-1}$. When these two absorbances were calculated as a ratio, the values obtained for the three materials were $0.22,0.56$ and 0.73 respectively, corresponding to carbohydrate/protein weight ratios of $0 \cdot 38,0.98$ and $1 \cdot 28$. 
C. PARVUM LYMPHORETICULAR-STIMULATING FRACTION
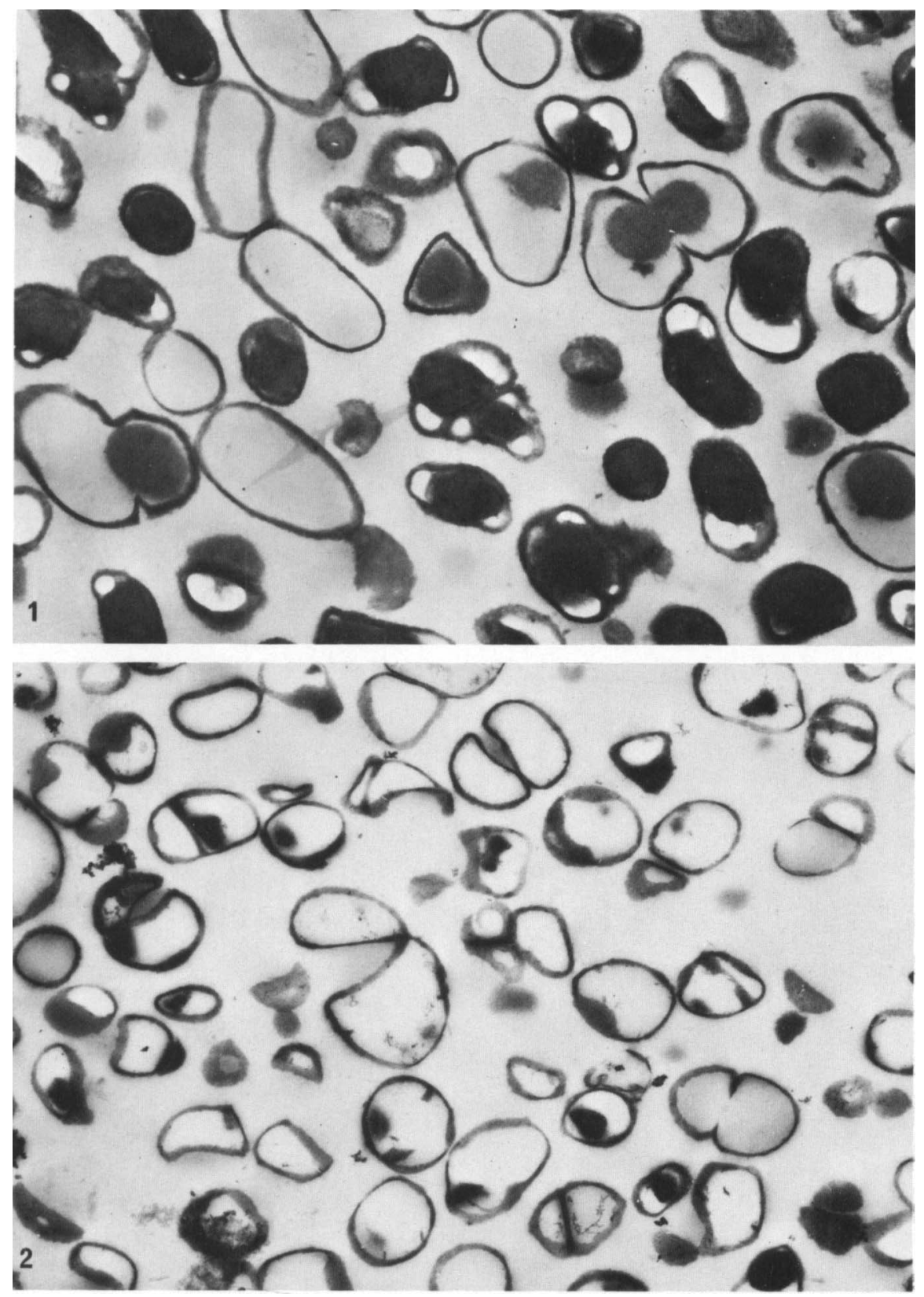

FIG. 1.-Residue of $C$. parvum after phenol-water extraction (PWIR). There is a mixture of apparently intact cells and others that have partially or wholly released their contents. EM. $\times 20300$.

FIG. 2.-Final product after full extraction procedure. It consists of the remains of cells from which nearly all the contents have been released. The cell walls retain their integrity. EM. $\times 27600$. 

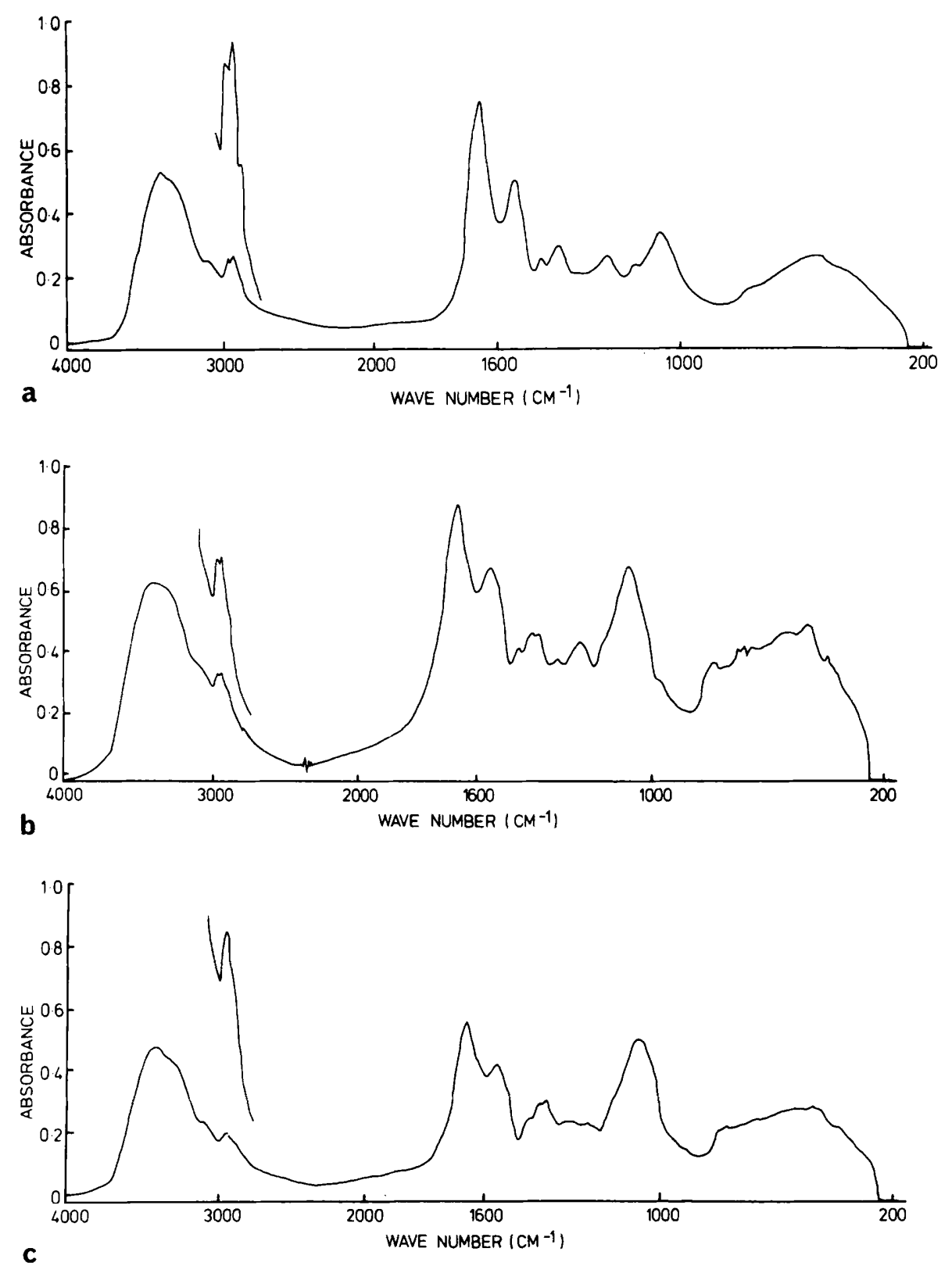

FIG. 3.-Infrared spectrum of: (a) the starting material: (b) phenol-water-insoluble residue (PWIR); (c) final product. 
With the increase in carbohydrate, there was a concomitant drop in $\mathrm{CH}$ absorbance at $2930 \mathrm{~cm}^{-1}$ during the purification process. Although lipid would account for most of the $\mathrm{CH}$ absorbance, carbohydrate and peptide chains also absorb in this region, albeit to a lesser extent. For this reason, spectra of dextran and bovine-serum albumin and spectra of the bacterial samples to which a known amount of liquid paraffin had been added were determined. Calculations from these traces gave values for the weight percentage of lipid hydrocarbon in the three samples as $2.9,0.68$ and 0 (all values $\pm 0 \cdot 2$ ) respectively. The values for starting material and for PWIR obtained by infrared measurements were thus appreciably larger than these values obtained by direct weighing although the values for the final product were comparable.

\section{Amino-acid chromatography}

Hydrolysates of the final product and of cell walls produced from the starting material were compared for amino-acid content by thin-layer chromatography (TLC). Spots corresponding to glutamic acid, glycine, alanine, diaminopimelic acid (DAP), muramic acid (faint) and glucosamine together with two unidentified blue spots were observed on both chromatograms. Galactosamine seen on the cell-wall chromatogram was not observed on that of the final product.

In an experiment in which PWIR was exhaustively digested with TCA, and TLC done on the resultant material which had been acid hydrolysed, it was noticeable that the unknown blue spots and the galactosamine spot were missing. This TCA-treated PWIR did not possess stimulatory activity.

\section{Nature of the two 'unknowns' present in the final product}

When the two unknown spots were eluted from thin-layer plates and examined further by infrared spectroscopy and mass spectroscopy (A.E.I. MS 902 Mass Spectrometer), both spots were clearly carbohydrate and indistinguishable from each other. By infrared spectroscopy some- $\mathrm{COOH}$ groups were evident but insufficient in quantity for the spots to have been uronic acids of monosaccharides - not more than a quarter of the rings would have had a- $\mathrm{COOH}$ group. The $\mathrm{C}-\mathrm{OH}$ absorption maximum was at higher frequencies $1075-1080 \mathrm{~cm}^{-1}$, as in galactose and mannose (not glucose). The nature of the $\mathrm{CH}$ absorption in the region of $1400 \mathrm{~cm}^{-1}$ suggested that the parent sugar was mannose rather than galactose, the principal maximum being at $1425 \mathrm{~cm}^{-1}$ with no appreciable absorption at $1320 \mathrm{~cm}^{-1}$ or $1450 \mathrm{~cm}^{-1}$ as would be expected from galactose.

By mass spectroscopy, the highest significant mass for both unknown samples was 162 , corresponding to $\mathrm{C}_{6} \mathrm{H}_{10} \mathrm{O}_{5}$ and this suffered successive losses of $18\left(\mathrm{H}_{2} \mathrm{O}\right)$ in the characteristic manner of carbohydrates. The fact that $\mathrm{C}_{6} \mathrm{H}_{12} \mathrm{O}_{6}$ was not observed implied that 162 arose from a polysaccharide. No mass containing nitrogen was observed but this may reflect destruction of a nitrogen-containing species during the pyrolysis conditions employed because both samples had produced a blue colouration with ninhydrin. 


\section{Amino-acid composition}

An amino-acid analysis performed on hydrolysed final material was compared with that of hydrolysed cell walls prepared from the starting material (table I). The major peaks observed were glutamic acid, glycine, alanine, DAP, glucosamine/galactosamine (appearing as one inseparable peak) and ammonia. Contamination of the final product with cytoplasmic amino acids appeared to be very low. A small peak due to muramic acid was observed in the analysis of the final product but was absent from the starting-material sample. Experiments to investigate this apparent absence of muramic acid showed that other preparations of strain CN6134 cell walls usually but not always gave a small muramic-acid peak. The variation in the height of this peak from one preparation to another suggested that optimal release of muramic acid was not being achieved by the hydrolysis conditions employed.

TABLE I

Amino-acid analysis of the final product and of cell walls prepared from the starting material

\begin{tabular}{lcc}
\hline \multicolumn{1}{c}{ Substance } & \multicolumn{2}{c}{ Molar ratio* of } \\
\cline { 2 - 3 } $\begin{array}{c}\text { cell walls prepared from the } \\
\text { starting material' }\end{array}$ & final product \\
\hline Aspartic acid & 0 & 0.09 \\
Threonine & 0 & 0.06 \\
Serine & 0 & 0.07 \\
Muramic acid & 0 & 0.32 \\
Glutamic acid & 0.85 & 1.06 \\
Glycine & 0.92 & 0.95 \\
Alanine & 1.36 & 1.41 \\
Valine & 0 & 0.07 \\
Diaminopimelic acid (DAP) & 1.0 & 1.0 \\
Leucine & 0 & 0.08 \\
Hexosamines & Not calculated & Not calculated \\
Lysine & $0 \cdot 15$ & 0.04 \\
Ammonia & Not calculated & Not calculated \\
\hline
\end{tabular}

*With respect to DAP.

tWashed whole organisms of the same batch used to prepare the final product were mechanically disintegrated and pronase-digested before hydrolysis (see Materials and methods).

\section{Sugar chromatography}

When the final product was hydrolysed and compared with the hydrolysate purified cell walls from the starting material on thin-layer chromatography for neutral sugars, spots corresponding to glucose, galactose and mannose appeared for both samples.

\section{Lymphoreticular stimulation and antitumour effect}

The increases of spleen and liver weight resulting from injection of starting material, phenol-water residue and final product are shown in table II. On a 
weight-for-weight basis the materials gave quantitatively similar results, with the phenol-water residue giving marginally better stimulation than either the starting material or final product.

In the anti-tumour test used, all three materials gave a quantitatively similar protection (table III).

TABLE II

Increase of spleen and liver weight by mice receiving whole Corynebacterium parvum starting material, phenol-water residue or final product

\begin{tabular}{|c|c|c|c|c|c|c|}
\hline \multirow{3}{*}{$\begin{array}{l}\text { Dose } \\
(\mathrm{mg})\end{array}$} & \multicolumn{6}{|c|}{ Weight ${ }^{*}$ of indicated organs after injection of } \\
\hline & \multicolumn{2}{|c|}{ starting material } & \multicolumn{2}{|c|}{ phenol-water residue } & \multicolumn{2}{|c|}{ final product } \\
\hline & Spleen & Liver & Spleen & Liver & Spleen & Liver \\
\hline $\begin{array}{c}1.40 \\
0.47 \\
0.15 \\
0 \text { (saline } \\
\text { only) }\end{array}$ & $\begin{array}{r}445 \pm 29 \\
331 \pm 25 \\
202 \pm 34 \\
90 \pm 7\end{array}$ & $\begin{array}{l}2328 \pm 99 \\
2268 \pm 116 \\
1642 \pm 169 \\
1052 \pm 30\end{array}$ & $\begin{array}{l}528 \pm 52 \\
322 \pm 26 \\
272 \pm 25\end{array}$ & $\begin{array}{l}2605 \pm 96 \\
1983 \pm 122 \\
1952 \pm 99\end{array}$ & $\begin{array}{l}452 \pm 24 \\
265 \pm 35 \\
215 \pm 13\end{array}$ & $\begin{array}{l}2344 \pm 93 \\
2000 \pm 84 \\
1682 \pm 91\end{array}$ \\
\hline
\end{tabular}

*Weights are $\mathrm{mg} / 20 \mathrm{~g}$ of body weight.

TABLE III

Anti-tumour effect of whole $C$. parvum starting material, phenol-water residue or final product against T3 fibrosarcoma

\begin{tabular}{c|ccc}
\hline & $\begin{array}{r}\text { Geometric mean (standard error) of number of tumour } \\
\text { nodules in lungs after injection of }\end{array}$ \\
Dose $(\mu \mathrm{g})$ & starting material phenol-water residue & final product \\
\hline 1400 & $2 \cdot 5(1 \cdot 4)$ & $2 \cdot 3(2 \cdot 0)$ & $3 \cdot 8(1 \cdot 7)$ \\
280 & $4 \cdot 4(1 \cdot 2)$ & $5 \cdot 3(2 \cdot 1)$ & $5 \cdot 5(1 \cdot 7)$ \\
56 & $31 \cdot 0(2 \cdot 1)$ & $56 \cdot 6(1 \cdot 0)$ & $21 \cdot 5(1 \cdot 3)$ \\
0 & $65 \cdot 7(1 \cdot 1)$ & & \\
(saline & & & \\
only) & & & \\
\hline
\end{tabular}

\section{Toxicity}

The effects of the three materials on mouse body-weight are recorded in table IV. The phenol-water residue and the final product produced a greater weight loss than the starting material.

When the three materials were compared for pyrogenicity in rabbits (table $\mathrm{V}$ ), the phenol-water residue was clearly more pyrogenic, causing not only higher temperature peaks, but also more double-peaked temperature rises. These second peaks were probably due to release of endogenous pyrogen. The difference between the final product and starting-material pyrogenicity was minimal. 
TABLE IV

Body weight of mice receiving whole C. parvum starting material, phenol-water residue or final product

\begin{tabular}{|c|c|c|c|c|c|c|}
\hline \multirow[b]{2}{*}{ Injected material } & \multirow[b]{2}{*}{ Dose (mg) } & \multicolumn{5}{|c|}{ Body weight* at days after injection: } \\
\hline & & 0 & 1 & 2 & 4 & 7 \\
\hline \multirow[t]{3}{*}{ Starting material } & $1 \cdot 40$ & 100 & $99 \cdot 2$ & $111 \cdot 1$ & $129 \cdot 4$ & $153 \cdot 1$ \\
\hline & 0.47 & 100 & $100 \cdot 4$ & 111.8 & $129 \cdot 5$ & 149.0 \\
\hline & $0 \cdot 16$ & 100 & $104 \cdot 2$ & 118.6 & 136.8 & $158 \cdot 3$ \\
\hline \multirow[t]{3}{*}{ Phenol-water residue } & 1.40 & 100 & 89.9 & 106.0 & $125 \cdot 1$ & 143.9 \\
\hline & 0.47 & 100 & 95.0 & $111 \cdot 2$ & $130 \cdot 9$ & 155.9 \\
\hline & $0 \cdot 16$ & 100 & $102 \cdot 2$ & 115.8 & 135.4 & 160.8 \\
\hline \multirow{3}{*}{ Final product } & 1.40 & 100 & $89 \cdot 3$ & 101.0 & $119 \cdot 8$ & $137 \cdot 4$ \\
\hline & 0.47 & 100 & 97.0 & 108.9 & $129 \cdot 6$ & 152.6 \\
\hline & $0 \cdot 16$ & 100 & $102 \cdot 7$ & 118.0 & $140 \cdot 6$ & 165.4 \\
\hline Saline & & 100 & $107 \cdot 0$ & $120 \cdot 7$ & $139 \cdot 7$ & $162 \cdot 4$ \\
\hline
\end{tabular}

* Results are expressed as a percentage of the starting weight.

TABLE V

Pyrogenicity of whole $C$. parvum starting material, phenol-water residue and final product for rabbits

\begin{tabular}{c|ccc}
\hline $\begin{array}{c}\text { Dose } \\
(\mathrm{mg})\end{array}$ & $\begin{array}{c}\text { Increase of rectal temperature }\left({ }^{\circ} \mathrm{C} \text {, mean for three ani- }\right. \\
\text { mals) after injection of }\end{array}$ \\
\hline 2.80 & 1.05 & $1.47^{*}$ & 1.07 \\
0.93 & 1.40 & $1.37 \dagger$ & 1.27 \\
0.31 & 0.85 & 1.13 & 1.23 \\
0 (saline & 0.10 & & \\
only) & & & \\
\hline
\end{tabular}

*All three animals in this group showed two temperature peaks. tOne of three animals in this group showed two temperature peaks.

\section{DisCUSSION}

By using whole rather than disintegrated organisms as starting material, we were able to obtain relatively clean cell walls from $C$. parvum which retained their integrity and also demonstrated the lymphoreticular-stimulating characteristics of the whole organism. The observation that phenol-water extraction of $C$. parvum is a useful primary purification compatible with the retention of stimulatory activity (Adlam et al., ) has been confirmed independently by other workers (Kouznetzova et al., 1974; Saino et al., 1976).

In our earlier studies, mild TCA digestion was employed to remove more unwanted cytoplasm. This often caused loss of activity and the use of dilute alkali has now been shown to be more useful. It is known that treatment with alkali can be used to advantage for processes in which bacterial cell-wall polymers are labile to acid hydrolysis (Archibald, Coapes and Stafford, 1969).

In the present experiments, TCA appeared to remove carbohydrate from 
PWIR. This is supported by the chromatographic evidence of loss of galactosamine in the final product, and the additional loss when exhaustive TCA treatment was employed, of the two blue carbohydrate compounds seen on amino-acid TLC plates. Because the peptidoglycan remaining after prolonged TCA digestion does not possess lymphoreticular-stimulating properties even though it appears very similar to the final product by electron microscopy, (Adlam and Reid, unpublished) the complete peptidoglycan/carbohydrate complex rather than the peptidoglycan alone, as we previously suggested (Adlam et al.. 1975), seems to be essential for activity.

Thin-layer chromatography of the final product for neutral sugars showed that the three hexoses-glucose, mannose and galactose-noted by Johnson and Cummins (1972) to be present in the cell walls of $P$. acnes type I, were all present. The fact that galactose is absent from cell walls of $P$. acnes type II (Johnson and Cummins, 1972), some strains of which may be as stimulatory as $P$. acnes type I (Adlam and Reid, 1977), strongly suggests that the galactose which Johnson and Cummins (1972) consider to be a terminal sugar in P. acnes type $\mathrm{I}$ is not necessary for activity.

Amino-acid analysis has shown the final product to be uncontaminated by cytoplasmic amino acids and gave a result similar to that obtained when disintegrated cell walls were analysed. The molar ratios with respect to DAP were similar to those obtained by Azuma et al., (1975) for a strain of P. acnes.

The lipid content of the final product, as measured either by weight of solvent-soluble material or by indirect infrared measurements at wavelengths at which $\mathrm{C}-\mathrm{H}$ bonds due to lipid are maximal, was very low. The higher values obtained for starting material and PWIR by infrared spectroscopy measurements as compared to direct weighing may reflect the presence of bound lipids in these samples that are not removed by the lipid-solvent procedures used. Nevertheless, because the final product had been extracted with chloroform in which both the lipid fractions of McBride et al., (1976) and Russell et al., (1976) are soluble and because the final product did not show typical lipid peaks by infrared spectroscopy as described by Russell et al. for their material, it must be assumed that the lipids described by these workers are absent.

'Total-carbohydrate' estimations gave rather higher values for the starting material and PWIR by the phenol/sulphuric acid method than for the anthrone method. This is probably due to the ability of the phenol/sulphuric acid method to detect nucleic acids. Because the values obtained for the three samples by either method were broadly similar, the carbohydrate enrichment observed by infrared measurements must represent an increase in the relative amount of those carbohydrates, e.g., the amino sugars that are not detectable by either the phenol/sulphuric acid or anthrone methods.

When the biological properties of the final product were compared with those of the starting and phenol-water insoluble materials, the final product appeared to have a specific activity approximately equivalent to the starting material in spleen-weight-increasing properties and in antitumour effect. However, because the yield of final product in a typical experiment was only $10-15 \%$, a large amount of 'activity' was lost during purification. This, 
combined with the failure of the extraction procedure materially to reduce toxicity, makes the material described here unlikely to merit serious consideration as a replacement for the whole organism currently undergoing clinical evaluation.

\section{SUMMARY}

A method is described in which washed whole cells of Corynebacterium parvum were chemically and enzymatically extracted to remove cytoplasm and cell-wall lipids. The resultant insoluble cell-wall residue possessed lymphoreticular stimulating properties as measured by their ability to increase spleen weight and protect against tumour-cell challenge. Analysis of the final product by chromatography and infrared spectroscopy has shown it to consist of carbohydrate and peptidoglycan, both of which appear to be necessary for the activities measured.

Thanks are due to Sheila Edkins and Mr R. N. Lucken for excellent technical assistance, and to Dr R. Bomford who kindly provided the tumour cells used in this study. Drs P. D. Ward, P. Novotny and P. D. Walker gave helpful advice and criticism of the manuscript.

\section{REFERENCES}

Adlam, C. AND REID, D.E. 1977. Comparative studies on the cell wall composition of some anaerobic coryneforms of varying lympho-reticular stimulatory activity. Devl. biol. Stand., 38, 115.

Adlam, C., Reid, D. E. and Torkington, P. 1975. The nature of the active principle of Corynebacterium parvum. In Corynebacterium parvum. Applications in experimental and clinical oncology. Proc. 1 st Int. Conf., Paris, 1974, edited by B. N. Halpern, New York, p. 35.

ADLAM, C. AND SCOTT, M. T. 1973. Lympho-reticular stimulatory properties of Corynebacterium parvum and related bacteria. J. med. Microbiol., 6, 261.

Archibald, A. R., Coapes, H. E. And StafFord, G. H. 1969. The action of dilute alkali on bacterial cell walls. Biochem. J., 113, 899.

Azuma, I., Sugimura, K., Taniyama, T., Aladin, A.A. and Yamamura, Y. 1975. Chemical and immunological studies on the cell walls of Propionibacterium acnes strain $\mathrm{C} 7$ and Corynebacterium parvum ATCC11829. Jap. J. Microbiol., 19, 265.

Cowgill, R. W. AND PARDEE, A. B. 1957. In Experiments in biochemical research techniques. New York, p. 52.

Cummins, C. S. AND Johnson, J. L. 1974. Corynebacterium parvum: a synonym for Propionibacterium acnes? J. gen. Microbiol., 80, 433.

Dawes, J., Tuach, S. J. AND MCBride, W. H. 1974. Properties of an antigenic polysaccharide from Corynebacterium parvum. J. Bact., 120, 24.

FAUVE, R. M. 1975. Stimulating effect of Corynebacterium parvum and C. parvum extract on the macrophage activities against Salmonella typhimurium and Listeria monocytogenes. In Corynebacterium parvum. Applications in experimental and clinical oncology. Proc. 1st Int. Conf., Paris, 1974, edited by B. N. Halpern, New York, p. 77.

Folch, J., Lees, M. AND Sloane-Stanley, G. H. 1957. A simple method for the isolation and purification of total lipides from animal tissues. J. biol. Chem., 226, 497.

GHUYSEn, J-M., TIPPER, D.J. AND STrominger, J.L. 1966. Enzymes that degrade bacterial cell walls. Meth. Enzymol., 8, 685. 
HANSEN, S. 1975. Thin-layer chromatographic method for the identification of mono-, di- and trisaccharides. J. Chromatog., 107, 224.

HaWORTH, C. AND HeathCote, J. G. 1969. An improved technique for the analysis of amino acids and related compounds on thin layers of cellulose. J. Chromatog., 41, 380.

Herbert, D., Phipps, P. J. and Strange, R. E. 1971. Chemical analysis of microbial cells. In Methods in microbiology $5 B$, edited by J. R. Norris and D. W. Ribbons, London, p. 209.

Johnson, J. L. AND Cummins, C. S. 1972. Cell wall composition and deoxyribonucleic acid similarities among the anaerobic coryneforms, classical propionibacteria, and strains of Arachnia propionica. J. Bact., 109, 1047.

Kouznetzova, B., Bizzini, B., Chermann, J-C., Degrand, F., Prévot, A-R. and Raynaud, M. 1974. Immunostimulating activity of whole cells, cell walls, and fractions of anaerobic corynebacteria. In Investigation and stimulation of immunity in cancer patients, edited by G. Mathé and R. Weiner, Recent results in cancer research, 47 Berlin, p. 275.

Lallouette, P., Bizzini, B., Maro, B. AND Schwarz, A. 1977. Studies on the immunostimulating and antitumour activity of a fraction isolated from Corynebacterium granulosum. Devl. biol. Stand. 38, 111.

MCBRIDE, W. H., DaWES, J. AND TUACH, S. 1976. Antitumour activity of Corynebacterium parvum extracts. J. natn. Cancer Inst., 56, 437.

Migliore-Samour, D., Korontzis, M., Jollès, P., Maral, R., Floc'h, F. and Werner, G. H. 1974. Hydrosoluble immunopotentiating substances extracted from Corynebacterium parvum. Immun. Comm. 3, 593.

Millman, I., Scott, A. W. ANd Halbherr, T. 1977. Antitumour activity of Propionibacterium acnes (Corynebacterium parvum) and isolated cytoplasmic fractions. Cancer Res., 37, 4150.

NovotNy, P. 1964. A simple rotary disintegrator for micro-organisms and animal tissues. Nature, Lond., 202, 364.

Palade, G. E. 1952. A study of fixation for electron microscopy. J. exp. Med., 95, 285.

Prévot, A-R., NGUYen-DANG, T. AND ThOUVENot, H. 1968. Influence des parois cellulaires du Corynebacterium parvum (Souche 936B) sur le système réticulo-endothélial de la souris. C.r. hebd. Séanc. Acad. Sci., Paris, 267, 1061.

Prévot, A-R., AND Thouvenot, H. 1964. Inhibition de la synthèse de la réticulostimuline chez les souches lysogènes de Corynebacterium anaérobies. C.r. hebd. Séanc. Acad. Sci., Paris, 259, 1447.

REYNOLDS, E. S. 1963. The use of lead citrate at high $\mathrm{pH}$ as an electron opaque stain in electron microscopy. J. Cell. Biol., 17, 208.

Riveros-Moreno, V., Bomford, R. AND SCOTT, M.T. 1978. Anti-tumour activity of purified cell walls from C. parvum. J. Natn. Cancer. inst., 60, 653 .

Russell, R. J., MCInroy, R. J., Wilkinson, P. C. AND WhITE, R. G. 1976. A lipid chemotactic factor from anaerobic coryneform bacteria including Corynebacterium parvum with activity for macrophages and monocytes. Immunology, 30,935.

Saino, Y., Eda, J., Nagoya, T., Yoshimura, Y., Yamaguchi, M. and Kobayashi, F. 1976. Anaerobic coryneforms isolated from human bone marrow and skin. Chemical, biochemical and serological studies and some of their biological activities. Jap. J. microbiol., $20,17$.

WestPhaL, O. AND JANN, K. 1965. Bacterial lipopolysaccharides. Extraction with phenolwater and further applications of the procedure. In Meth. carbohyd. Chem., edited by R. L. Whistler, London, 5, 83. 